\title{
Risk Assessment for Karnal Bunt Occurrence in the Pacific Northwest
}

\author{
Richard W. Smiley, Professor of Plant Pathology, Oregon State University, Columbia Basin Agricultural Research \\ Center, P.O. Box 370, Pendleton 97801
}

\begin{abstract}
Smiley, R. W. 1997. Risk assessment for Karnal bunt occurrence in the Pacific Northwest. Plant Dis. 81:689-692.

Tilletia indica, the causal agent of Karnal bunt of wheat, was first detected and reported in the United States in 1996. Karnal bunt occurred in the southwestern United States as early as 1992. Wheat contaminated with teliospores of $T$. indica is likely to have been transported from the Southwest to other regions, including the Pacific Northwest, before presence of the pathogen was discovered. Teliospore and sporidial germination and infection are highly dependent on climatic conditions. The potential for $T$. indica to infect wheat in the Pacific Northwest has not been reported. The objective of this study was to use published information on environmental factors favorable for infection and historical climate data for the Pacific Northwest to analyze the environmental risk for Karnal bunt to occur if wheat fields in the Pacific Northwest become contaminated by $T$. indica. Conditions during the past four decades appeared favorable for infection in nonirrigated wheat during 1 of every 3 years at two (Corvallis, OR, and Spokane, WA) of 13 Idaho, Oregon, and Washington locations examined, and every year at all locations where wheat is irrigated. If introduced to the area, it appears possible for T. indica to become established in selected regions of the Pacific Northwest.
\end{abstract}

Additional keywords: Neovossia indica, Triticum aestivum

Tilletia indica Mitra (=Neovossia indica (Mitra) Mundkur) causes Karnal bunt of wheat (Triticum aestivum L.) and has been recognized in North America for less than three decades $(1,7,25)$. The reported distribution of $T$. indica is restricted to a few countries $(1,25)$, and other countries that import wheat for processing or seed employ quarantines to impede the introduction of this pathogen. Most quarantines have zero tolerance for $T$. indica teliospores (USDA-Animal and Plant Health Inspection Service, Plant Protection and Quarantine [USDA-APHIS-PPQ] Phytosanitary Notes; current listings at: http://www.aphis.usda.gov/oa/bunt). Consequences of contamination are severe for wheat-producing regions such as the $\mathrm{Pa}$ cific Northwest, from which $85 \%$ of the 8.3 million $\mathrm{Mg}$ of wheat produced is exported to overseas customers. Major shifts in markets and prices are possible if $T$. indica is introduced and becomes established in the Pacific Northwest.

The first report of Karnal bunt in the United States, during 1996, involved wheat

Corresponding author: R. W. Smiley
E-mail: smileyr@ccmail.orst.edu

Accepted for publication 25 February 1997.

Publication no. D-1997-0422-05S

(C) 1997 The American Phytopathological Society produced in Arizona during 1995 (27). The USDA-APHIS-PPQ implemented a program (2) to eradicate $T$. indica from areas known or thought to be infested and to prevent further export of $T$. indica-contaminated seed, products, equipment, and transport containers from areas where Karnal bunt occurred (Karnal Bunt Quarantine, Federal Register, 28 March 1996). The pathogen was subsequently discovered in wheat produced in at least three southeastern states (Alabama, Georgia, and Tennessee). A Tilletia species, possibly $T$. indica, was also detected in ryegrass (Lolium multiflorum and L. perenne) seed produced in the Willamette Valley of western Oregon (D. Hilburn, personal communication). The pathogen is present in $60 \%$ of ryegrass seed lots, has been detected in seed packaged as early as 1989, and is present in ryegrass seed imported into Oregon from at least nine other countries. $T$. indica has not been detected in wheat produced in the Pacific Northwest states of Idaho, Oregon, and Washington, including nearly a thousand wheat samples collected in Oregon, and wheat produced adjacent to ryegrass fields. Although ryegrasses are susceptible to infection by $T$. indica (17), it is not yet known whether the ryegrass pathogen can infect wheat. Nevertheless, the head smut occurring on ryegrass in the Pacific Northwest emphasizes the need to evaluate the potential for $T$. indica to become established on wheat in the region.
It is difficult to detect Karnal bunt in the field. Teliospores of $T$. indica are most easily detected in harvested grain by clinical diagnostic procedures (1). Information gathered during the eradication program in 1996 indicated that Karnal bunt occurred in Arizona and California as early as 1992 (M. Nelson, personal communication; USDA-APHIS-PPQ Situation Report for 29 March 1996, listed at: http://www. aphis.usda.gov/oa/bunt). Seed from these states was distributed to farmers, millers, storage elevators, and wheat breeding and testing programs in other states before it was discovered that the seed was contaminated with teliospores of T. indica (USDAAPHIS-PPQ Situation Reports for 20, 22, and 29 March and 1 and 17 April 1996, listed at: http://www.aphis.usda.gov/oa/bunt). For instance, wheat produced in Arizona and California was milled at Pendleton, Oregon; and milling by-products were transported to Washington and other states for further processing into pet food. Wheat seed produced in Arizona was also planted in commercial fields and wheat breeding nurseries throughout the Pacific Northwest. T. indica teliospores were surely transported to other states via seed, grain, and contaminated equipment before the pathogen was detected in the United States.

The potential for $T$. indica to survive and infect wheat under climatic conditions in the Pacific Northwest has not been reported. Data from other regions indicate that the potential geographic range for Karnal bunt is restricted less by physical requirements for survival of $T$. indica teliospores than by synchronization of wheat heading with climatic conditions favorable for teliospore germination, secondary sporidial multiplication, and penetration and infection.

Survival of teliospores through the winter seems likely in most wheat-producing locations in the Pacific Northwest. Teliospores of T. indica are durable and persist in soil for up to 4 years. Survival in field soil varies greatly in response to depth of burial, soil moisture and temperature, and perhaps other factors $(12,21)$. Teliospore survival is relatively unaffected by freezing for several months at $0^{\circ} \mathrm{C}(20)$, and survival is reduced only slightly by deep freezing $\left(-18^{\circ} \mathrm{C}\right)$ in soil for 20 weeks (5). Subfreezing temperatures required to in- 
hibit $T$. indica teliospore viability do not occur for sufficient times at any Pacific Northwest location where wheat is produced. For instance, at Pocatello, Idaho, the coldest wheat-producing location in the region, air temperature records indicate that $-18^{\circ} \mathrm{C}$ is attained for only 2 days each year (averaged over 54 years of records) and that the length of freezing below $-1{ }^{\circ} \mathrm{C}$ averages 68 days per year (R. W. Rickman, personal communication). At Corvallis, Oregon, the mildest climate in the region, air temperatures are below $-1^{\circ} \mathrm{C}$ an average of 6 days per year and never reach $-18^{\circ} \mathrm{C}$.

Humidity at the time of heading appears to be the most important environmental factor for Karnal bunt occurrence $(3,18,26)$. Teliospores of $T$. indica at the soil surface germinate and produce primary sporidia, which in turn produce secondary sporidia that are forcibly ejected under cool, moist conditions $(1,25)$. Sporidia are released mostly during early morning when relative humidity and leaf wetness are highest. Secondary sporidia that land on moist foliage can germinate and produce additional secondary sporidia or hyphae that produce secondary sporidia. Hyphae from secondary sporidia infect through stomates in glumes of emerged wheat spikes (8). Sporidia may also be washed down into the flag leaf sheath, onto unemerged or emerging heads. Survival of sporidia and infection are favored by cool temperature (16 to $26^{\circ} \mathrm{C}$ optimum, 7 to $11^{\circ} \mathrm{C}$ minimum) and either high humidity $(>70 \%)$ or rainfall that produces high humidity during several successive days $(9,11,14,18,19,21,22)$. Although physical requirements for infection are not well defined, successful inoculations have been achieved from airborne sporidia landing on wheat heads incubated at high humidity for less than $24 \mathrm{~h}$ (8). Under field conditions, sporidia and mycelia presumably dehydrate, and infection is reduced or prevented if humidity declines and solar radiation is high for even short periods during the day. Under experimental conditions, secondary sporidia have survived 2 and $12 \mathrm{~h}$ at 25 and 95\% relative humidity, respectively (21). Droplets of condensation or guttation trapped in wheat heads would be expected to extend the effective wetting period when humidity is low. Humidity inside the leaf sheath also remains high for unemerged heads and portions of emerging heads.

The objective of this study was to estimate the environmental risk for Karnal bunt to occur if soils become contaminated by $T$. indica at 13 Pacific Northwest locations. This was accomplished by (i) defining, from the literature, minimal climatic and plant growth requirements for Karnal bunt to occur, and (ii) analyzing historical data to determine the frequency at which climatic requirements for infection were satisfied during heading.

\section{MATERIALS AND METHODS}

Historic temperature records representing the range of climatic zones of the $\mathrm{Pa}$ cific Northwest where wheat is grown (6) were examined for weather conditions conducive to infection immediately preceding and during heading.

Weather data were obtained from the Hydrosphere Data Products, Inc. (Boulder, CO 80302) summary of the National Climatic Data Center's daily temperature and precipitation records. Thirteen locations were selected in Idaho (ID), Oregon (OR), and Washington (WA). Their identification codes in the Center's data record were the following: MOSCOW U OF IDAHO (Latah Co., ID, \#6152); POCATELLO WSO AP (Power Co., ID, \#7211); CORVALLIS ST UNIV (Benton Co., OR, \#1862); LA GRANDE (Union Co., OR, \#4622); MORO (Sherman Co., OR, \#5734); NYSSA (Malheur Co., OR, \#6179); PENDLETON BR EXP STN (Umatilla Co., OR \#6540); PENDLETON WSO AP (Umatilla Co., OR, \#6546); PILOT ROCK 1 SE (Umatilla Co., OR,
\#6634); LIND 3 NE (Adams Co., WA, \#4679); MOSES LAKE 3E (Grant Co., WA, \#5613); QUINCY 1S (Grant Co., WA, \#6880); and SPOKANE WSO AP (Spokane Co., WA, \#7938). Generalized climatic data for most of the Oregon and Washington locations were reported $(6,23)$. In the occasional cases where temperature data were missing, maximum or minimum temperature was estimated as the average of values from the preceding and following days. When multiple data were missing within the interval of concern, the year was eliminated from the analysis.

Criteria for examining weather records were synthesized from existing reports describing conditions in which the disease did or did not occur $(3,11,14,18)$ and from predictive models for Karnal bunt $(9,19)$. These conditions were compared with those that occur during heading of springand autumn-planted wheat in the Pacific Northwest. Heading occurs from early May to late June, depending on location and planting date. For this study, four time intervals were examined: 1 May to 30 June (60 days), 7 May to 22 June (45 days), 15 May to 15 June (31 days), and 22 May to 7 June (16 days). The longest interval slightly exceeds the range of heading dates, and the shortest interval is shorter than the range of heading dates at all sites.

For infection to occur, it was assumed that measurable rain $(>3 \mathrm{~mm})$ had to occur on each of two or more successive days, at least $10 \mathrm{~mm}$ must be collected within the 2-day interval, and average daily relative humidity above the plant canopy must exceed $70 \%$ during both days. Humidity was estimated as the ratio of saturation vapor pressures at the average and minimum daily temperatures. Saturation vapor pressure was computed with the GoffGratch formulas obtained from the Smithsonian Meteorological Tables (13). Minimum temperature was assumed to be dew point. Numbers and percentages of years with at least one potential "infection pe-

Table 1. Number of years and proportion (\%) of years tested with favorable weather events ${ }^{\mathrm{a}}$ for infection of wheat by Tilletia indica during heading at 13 locations in the Pacific Northwest

\begin{tabular}{|c|c|c|c|c|c|c|c|c|c|}
\hline \multirow[b]{3}{*}{ Location } & \multirow{3}{*}{$\begin{array}{c}\text { Data record } \\
\text { (years) }\end{array}$} & \multicolumn{8}{|c|}{ Possible infection events during the heading interval } \\
\hline & & \multicolumn{2}{|c|}{1 May to 30 June } & \multicolumn{2}{|c|}{7 May to 22 June } & \multicolumn{2}{|c|}{15 May to 15 June } & \multicolumn{2}{|c|}{22 May to 7 June } \\
\hline & & (years) & $(\%)$ & (years) & $(\%)$ & (years) & $(\%)$ & (years) & $(\%)$ \\
\hline Corvallis, OR & 46 & 44 & 96 & 39 & 85 & 34 & 74 & 25 & 54 \\
\hline LaGrande, OR & 30 & 28 & 93 & 27 & 90 & 21 & 70 & 13 & 43 \\
\hline Moscow, ID & 47 & 38 & 81 & 33 & 70 & 27 & 57 & 16 & 34 \\
\hline Spokane, WA & 47 & 43 & 91 & 36 & 77 & 28 & 60 & 16 & 34 \\
\hline Pocatello, ID & 47 & 37 & 79 & 34 & 71 & 26 & 55 & 12 & 26 \\
\hline Pendleton Airport, OR & 64 & 45 & 70 & 45 & 72 & 25 & 53 & 15 & 32 \\
\hline Pendleton Exp. Stn., OR & 38 & 24 & 63 & 23 & 61 & 18 & 47 & 11 & 29 \\
\hline Pilot Rock, OR & 41 & 25 & 61 & 23 & 56 & 16 & 39 & 7 & 17 \\
\hline Moro, OR & 65 & 31 & 48 & 28 & 43 & 22 & 34 & 14 & 22 \\
\hline Nyssa, OR & 42 & 17 & 40 & 14 & 33 & 12 & 29 & 10 & 24 \\
\hline Quincy, WA & 52 & 17 & 33 & 15 & 29 & 14 & 27 & 7 & 13 \\
\hline Lind, WA & 65 & 27 & 42 & 25 & 38 & 16 & 25 & 11 & 17 \\
\hline Moses Lake, WA & 28 & 13 & 46 & 12 & 43 & 7 & 25 & 3 & 11 \\
\hline
\end{tabular}

a Favorable weather conditions defined as: (i) measurable rain $(>3 \mathrm{~mm})$ occurred on each of two or more successive days, (ii) at least $10 \mathrm{~mm}$ was collected within the 2-day interval, and (iii) average relative humidity above the plant canopy exceeded $70 \%$ during both days. 
riod," based on average air temperature as previously described, were determined for each of the four heading intervals, for 13 locations in the Pacific Northwest.

For locations with a $50 \%$ or greater probability of infection during the longest interval tested, the frequency of possible infection events was reevaluated under two more conservative estimates of humidity. The conservative estimates were made because humidity calculated from daily average temperature does not adequately reveal the duration of low humidity which can dehydrate sporidia and hyphae. The most conservative (driest) estimate used maximum daily temperatures, and an intermediate estimate used the minimum and one degree $\left(1^{\circ} \mathrm{C}\right)$ lower than maximum daily air temperature. Humidity computed from maximum daily temperature indicates the minimum humidity for the day, but the interval of time for that maximum temperature and minimum humidity may be brief $(<1 \mathrm{~h})$. The interval of time that daily temperature is at or above $1^{\circ} \mathrm{C}$ less than the daily maximum will almost always exceed 2 h. Humidity computed from that temperature (maximum minus $1^{\circ} \mathrm{C}$ ) would occur for a sufficient time to determine the presence or absence of free moisture on heads of nonirrigated wheat.

Temperature was not used as a limiting factor in this study because temperatures occurring during heading in the Pacific Northwest were always well within the limits of optimum $\left(16\right.$ to $\left.26^{\circ} \mathrm{C}\right)$ and minimum $\left(7\right.$ to $\left.11^{\circ} \mathrm{C}\right)$ temperatures when Karnal bunt occurs in other regions.

\section{RESULTS AND DISCUSSION}

Environmental conditions appear favorable for T. indica to cause Karnal bunt in irrigated and high humidity wheat-producing regions of the Pacific Northwest. Table 1 presents the number of years for each location that at least one potential infection period occurred. These data, based on humidity at average daily temperature, include many years that were conducive for multiple or prolonged infection events. The locations are listed in the order of greatest to lowest probability of infection for the four time intervals. Based on the second shortest heading interval, 15 May to 15 June, six of the 13 sites have possible infection periods at least half of the time. The five driest locations, Lind, Moro, Moses Lake, Nyssa, and Quincy, have possible infection periods in only 2 or 3 of every 10 years. Teliospores survive in some soils for up to 4 years. Since there are intervals of 4 years or more in the weather records from the dry locations when no weather conditions that produce a possible infection event occur, even when average daily relative humidity is used as the basis for calculations, they would not be expected to be favorable habitats for $T$. indica to survive under nonirrigated production conditions.

Predicted occurrences of infection periods are markedly influenced by the method used to calculate relative humidity (Table $2)$. The basis for previous reports included minimum daily (9), average daily (16), and average weekly (19) relative humidity. For purposes of this study, the most realistic estimate of relative humidity was considered to be the estimate based on the average of the minimum and maximum minus $1^{\circ} \mathrm{C}$ daily temperature. Using this criterion, all except two locations had less than 1 year in 5 for naturally occurring infection opportunities between 15 May and 15 June (Table 2). In these locations, conditions for potential infection events occur infrequently enough that $T$. indica would not be expected to sustain itself in nonirrigated cropping systems. However, at two locations, Corvallis, OR, and Spokane, WA, the potential for naturally occurring infection occurs with a probability of about 1 year in 3. If a more liberal estimate of humidity is used at these two locations, the predicted potential for infection exceeds 6 of every 10 years. Possible infection events at these two locations occur frequently enough that $T$. indica would be expected to sustain itself in rotations that include wheat at least every third year. Wheat is a major crop in these locations and is often produced during alternate years. For instance, the Willamette Valley of Oregon, represented in this survey by the Corvallis site, produces $16 \%$ of the wheat and $95 \%$ of the ryegrass in Oregon.

Atmospheric conditions required for Karnal bunt appear to closely parallel those for wheat head scab, caused by species of Fusarium (15), and potato late blight, caused by Phytophthora infestans (10). Wheat head scab and potato late blight both occur in the Pacific Northwest. Head scab occurs in irrigated wheat (24) and in high mountain valleys (23), where the growing season is extended into late summer or early autumn. Late blight occurs where potatoes are grown under sprinkler irrigation in rotation with wheat and other crops (10). In Arizona, where wheat and potatoes are watered by furrow irrigation, the area of Karnal bunt occurrence during 1995 coincided with that of late blight (M. Nelson, personal communication). The vast sprinkler-irrigated region of the $\mathrm{Pa}$ cific Northwest appears to have a higher risk for infection of wheat by $T$. indica than would occur in the nonirrigated regions evaluated in this study.

Irrigation is known to favor the occurrence of Karnal bunt (4). Providing that soils are contaminated, an opportunity for infection appears to occur every year at all Pacific Northwest locations when overhead irrigation water is applied during heading. Approximately $20 \%$ of wheat in Oregon and Washington is produced with sprinkler irrigation. More than half the production in Idaho is irrigated, with sprinkler irrigation being dominant in eastern Idaho. Most wheat near Moses Lake, Nyssa, Quincy, and Pocatello is irrigated. It is common for water to be applied at each location until the plant is mature.

This analysis was restricted to climatic conditions required for sporidial release, survival, and infection. However, the likelihood for disease to occur is also highly dependent upon poorly defined aspects of teliospore population dynamics (26), including level of initial soil contamination, survival over time, depth of burial in soil, and synchronization of germination with

Table 2. Proportion of years with favorable weather events ${ }^{\mathrm{a}}$ for infection of wheat by Tilletia indica during heading at eight locations in the Pacific Northwest, based on calculations of minimum humidity at average daily temperature (ave; the least conservative estimate), maximum temperature minus $1^{\circ} \mathrm{C}$ (max-1; the most likely estimate), or maximum daily temperature (max; the most conservative estimate)

\begin{tabular}{|c|c|c|c|c|c|c|c|c|c|c|c|c|}
\hline \multirow[b]{3}{*}{ Location } & \multicolumn{12}{|c|}{ Possible infection events (\% years) during the heading interval } \\
\hline & \multicolumn{3}{|c|}{1 May to 30 June } & \multicolumn{3}{|c|}{7 May to 22 June } & \multicolumn{3}{|c|}{15 May to 15 June } & \multicolumn{3}{|c|}{22 May to 7 June } \\
\hline & (ave) & $(\max -1)$ & $(\max )$ & (ave) & $(\max -1)$ & $(\max )$ & (ave) & $(\max -1)$ & $(\max )$ & (ave) & $(\max -1)$ & $(\max )$ \\
\hline Spokane, WA & 92 & 55 & 30 & 77 & 51 & 30 & 60 & 36 & 23 & 34 & 17 & 17 \\
\hline Corvallis, OR & 96 & 45 & 23 & 85 & 34 & 15 & 74 & 30 & 11 & 54 & 19 & 4 \\
\hline Pendleton Airport, OR & 68 & 23 & 13 & 68 & 19 & 11 & 53 & 19 & 11 & 32 & 9 & 4 \\
\hline Pilot Rock, OR & 61 & 32 & 12 & 56 & 20 & 10 & 39 & 15 & 7 & 17 & 5 & 2 \\
\hline Moscow, ID & 81 & 19 & 11 & 70 & 19 & 11 & 57 & 11 & 6 & 34 & 6 & 2 \\
\hline Pocatello, ID & 79 & 28 & 11 & 72 & 21 & 6 & 55 & 13 & 2 & 26 & 4 & 0 \\
\hline La Grande, OR & 93 & 27 & 10 & 90 & 23 & 10 & 67 & 17 & 7 & 47 & 10 & 3 \\
\hline Pendleton Exp. Stn., OR & 63 & 16 & 8 & 61 & 11 & 3 & 47 & 8 & 3 & 29 & 5 & 3 \\
\hline
\end{tabular}

a Favorable weather conditions defined as: (i) measurable rain $(>3 \mathrm{~mm})$ occurred on each of two or more successive days, (ii) at least $10 \mathrm{~mm}$ was collected within the 2-day interval, and (iii) average relative humidity above the plant canopy exceeded $70 \%$ during both days. 
wheat heading. For instance, it is possible for survival of teliospores to be shorter in irrigated than in nonirrigated soils (21), to be less when teliospores are buried by tillage rather than left at the soil surface (21), and to germinate under favorable environmental conditions at times when wheat is not heading (20-22). It is also probable for wheat to be produced less frequently in irrigated than in nonirrigated fields. Collectively, these conditions could ameliorate the high risk associated with favorable infection periods in irrigated soils of the Pacific Northwest.

Additional investigations of teliospore population dynamics are needed to provide more specific information regarding the risk of Karnal bunt under a range of crop management conditions in the Pacific Northwest and other wheat-production regions in the United States.

\section{ACKNOWLEDGMENTS}

Assistance with data collection and analysis by Ronald Rickman, USDA-Agricultural Research Service, is greatly appreciated. I also thank Edwin Civerolo, Guillermo Fuentes-Davila, Robert Forster, Blaire Goates, Robert Metzger, Merritt Nelson, and Joseph Smilanick for guidance in preparing this manuscript. Financial assistance was provided by the Oregon Wheat Commission. Oregon Agric. Exp. Stn. Technical Paper No. 11024.

\section{LITERATURE CITED}

1. Agarwal, V. K., Singh, D. V., and Mathur, S. B. 1993. Karnal bunt (Tilletia indica). Pages 31-43 in: Seed-borne Diseases and Seed Health Testing of Wheat. S. B. Mathur and B. M. Cunfer, eds. Danish Gov. Inst. Seed Pathol., Hellerup, Denmark.

2. Anonymous. 1983. Action plan on Karnal bunt, Neovossia indica (Mitra) Mundkur. USDA-APHIS Plant Prot. Quarantine.

3. Aujla, S. S., Sharma, Y. R., Chand, K., and Sawney, S. S. 1977. Influence of weather factors on the incidence and epidemiology of karnal bunt disease of wheat in the Punjab. Indian J. Ecol. 4:71-74.
4. Bedi, S. K. S., Sikka, M. R., and Mundkur, B. B. 1949. Transmission of wheat bunt due to Neovossia indica (Mitra) Mundkur. Indian J. Phytopathol. 2:20-26.

5. Chalal, S. S., and Mathur, S. B. 1992. Germination of deep-frozen Tilletia indica and Tilletia barclayana teliospores. FAO Plant Prot. Bull. 40:31-35.

6. Douglas, C. L., Jr., Rickman, R. W., Klepper, B. L., Zuzel, J. F., and Wysocki, D. J. 1992. Agroclimatic zones for dryland winter wheat producing areas of Idaho, Washington, and Oregon. Northwest Sci. 66:26-34.

7. Duran, R. 1972. Further aspects of teliospore germination in North American smut fungi II. Can. J. Bot. 50:2569-2573.

8. Goates, B. 1988. Histology of infection of wheat by Tilletia indica, the Karnal bunt pathogen. Phytopathology 78:1434-1441.

9. Jhorar, O. P., Mavi, H. S., Sharma, I., Mavi, G. S., Mathauda, S. S., Gurmeet-Singh, and Singh, G. 1992. A biometeorological model for forecasting Karnal bunt disease of wheat. Plant Dis. Res. 7:204-209.

10. Johnson, D. A., Alldredge, J. R., and Vakoch, D. L. 1996. Potato late blight forecasting models for the semiarid environment of south-central Washington. Phytopathology 86:480-484.

11. Khetarpal, R. K., Agarwal, V. K., and Chauhun, K. P. S. 1980. Studies on the influence of weather conditions on the incidence of blackpoint and Karnal bunt of triticale. Seed Res. 8:108-110.

12. Krishna, A., and Singh, R. A. 1983. Longevity of teliospores of Neovossia indica causing Karnal bunt of wheat. Indian J. Mycol. Plant Pathol. 13:97-98.

13. List, R. J. 1968. Smithsonian Meteorological Tables. Smithsonian Institution, Washington, DC.

14. Mavi, H. S., Jhorar, O. P., Sharma, I., Gurmeet-Singh, Mahi, G. S., Mathauda, S. S., Aujla, S. S., and Singh, G. 1992. Forecasting Karnal bunt disease of wheat - a meterological method. Cereal Res. Comm. 20:1-2, 6774.

15. Parry, D. W., Jenkins, P., and McLeod, L. 1995. Fusarium ear blight (scab) in small grain cereals - a review. Plant Pathol. 44:207238.

16. Perring, T. M., Adams, C. J., Siebert, J. B., Holmes, G. J., Jackson, L., and Kallenbach,
R. L. 1996. Likelihood of Karnal bunt spread from wheat harvested in the Imperial and Palo Verde Valleys of California: A scientificbased, site-specific probabilistic risk assessment, weather analysis and economic impact study. University of California, College of Nat. and Agric. Sci., Riverside.

17. Royer, M. H., and Rytter, J. 1988. Comparison of host ranges of Tilletia indica and $T$. barclayana. Plant Dis. 72:133-136.

18. Singh, A., and Prasad, R. 1978. Date of sowing and meteorological factors in relation to occurrence of Karnal bunt of wheat in U. P. Tarai. Indian J. Mycol. Plant Pathol. 8:2.

19. Singh, D., Singh, R., Rao, V., Karwasra, S. S., and Beniwal, M. S. 1996. Relation between weather parameters and karnal bunt (Neovossia indica) in wheat (Triticum aestivum). Indian J. Agric. Sci. 66:522-525.

20. Smilanick, J. L., Hoffman, J. A., and Royer, M. H. 1985. Effect of temperature, pH, light, and desiccation on teliospore germination of Tilletia indica. Phytopathology 75:14281431.

21. Smilanick, J. L., Prescott, J. M., Hoffman, J. A., Secrest, L. R., and Weise, K. 1989. Environmental effects on survival and growth of secondary sporidia and teliospores of Tilletia indica. Crop Prot. 8:86-90.

22. Smilanick, J. L., Secrest, L. R., Weise, K., and Hoffman, J. A. 1987. Survival and growth of secondary sporidia of Tilletia indica at various relative humidities and temperatures. (Abstr.) Phytopathology 77:1700.

23. Smiley, R. W., and Patterson, L.-M. 1996 Pathogenic fungi associated with Fusarium foot rot of winter wheat in the semiarid $\mathrm{Pa}$ cific Northwest. Plant Dis. 80:944-949.

24. Strausbaugh, C. A., and Maloy, O. C. 1986. Fusarium scab of irrigated wheat in central Washington. Plant Dis. 70:1104-1106.

25. Warham, E. J. 1986. Karnal bunt disease of wheat: A literature review. Trop. Pest Manage. 32:229-242.

26. Warham, E. J., and Flores, D. 1988. Farmer surveys on the relation of agronomic practices to Karnal bunt disease of wheat in the Yaqui Valley, Mexico. Trop. Pest Manage. 34:373381.

27. Ykema, R. E., Floyd, J. P., Palm, M. E., and Peterson, G. L. 1996. First report of Karnal bunt of wheat in the United States. Plant Dis. 80:1207. 